\section{Competition reaps rewards \\ Washington}

A STUDY of US agricultural research now being circulated to colleges and universities offers encouragement to scientists and may pave the way for more coherent planning. The report* emphasizes the need for improved communications between Congress and the executive so that scientific projects do not become hostages to political fortune, and may lead to an expansion of competitive grant funding. This would bring benefits to the underdeveloped plant biotechnology research programme.

The timing of the report is apt: next year's agriculture appropriations bill remains jammed in Congress. The Senate has restored the administration's $\$ 50$ million budget request for the Department of Agriculture's competitive grants programme after the House sought to cut this to $\$ 17.5$ million. The $\$ 50$ million includes $\$ 28.5$ million allocated to the administration's new biotechnology initiative. Although no conference committee has yet been appointed to bridge the gap, much behind-the-scenes negotiating is going on. But despite the generally favourable light in which science is regarded in Congress, prominent figures in the House consider basic research in agriculture irrelevant to the immediate needs of farmers.

The report now being circulated was prepared under contract for the Department of Agriculture as an "action research programme", involving scores of interviews. It is heavy with sociological theorizing and even ventures some speculations on philosophical issues: for example, the "logical positivistic" underpinnings of agricultural research are blamed for the "paradox of faith in science leading to doubt and distrust". But there are also some more concrete suggestions, chief among which is a proposal for a new National Agricultural Issues Commission based within the National Academy of Sciences which would define long-term research goals.

Ironically, that proposal is the one that seems least likely to get anywhere. A majority of the key decision makers who reviewed a draft of the report felt that two existing bodies - the Joint Council on Food and Agricultural Sciences and the Users Advisory Board - could do the job.

Many of the report's other conclusions have been well received, although a proposal for new centres of excellence in agricultural research is contentious. The report urges efforts to broaden recruitment to bring in more students from non-farm backgrounds, and argues for increased prominence and status for scientists. A separate study being completed by Professor Irwin Feller of Pennsylvania State University, shortly to be delivered to the agriculture department, is thought to have a similarly up-beat approach towards future contributions of research.

The combined impact of both studies is likely to have a "slow but significant effect" on policy, according to Dr John Jordan, administrator of the agriculture department's cooperative state research service. The activity of recent months has brought together congressmen and scientists "who would never normally see each other". The use of competitive grants to fund research is now likely to increase, thus allowing major research centres outside the land-grant system to make bids. And even the land-grant colleges are starting to make more use of competitive schemes and joint schemes with non-landgrant institutions, says Jordan.

Tim Beardsley

*The Paradox of Success: The Impact of Priority Setting in Agricultural Research and Extension, (US Department of Agriculture).

\title{
New US genetics centre goes west
}

\section{San Francisco}

A NEW research centre concerned with genetic engineering of crop plants has been established jointly by the US Department of Agriculture (USDA) and the University of California. The centre hopes to attract university and industry researchers from all over the world to work on basic research projects in plant genetics and gene expression.

The Plant Gene Expression Center, with an initial annual budget of $\$ 4$ million, will be housed in USDA's Western Regional Research Center in Albany, near the Berkeley campus of the university. The facility has laboratory space for about 40 researchers and is expected to be operational within a year. Ten senior scientists will form the foundation of the centre, including two senior scientist programme leaders holding university appointments. The remaining eight core scientists will hold positions with USDA's Agricultural Research Service (ARS).

The core group will be supported by a consortium of public and private researchers. The consortium serves as a source of expertise and provides an important link with other research institutions and industry. In addition, a science advisory committee will be formed to help set research priorities.

The centre will investigate basic questions in plant molecular biology, using and further developing new tools of plant genetic engineering. The centre wants to make its research findings available to anyone, including those interested in developing marketable products. Details of publication policy have not yet been worked out, according to Gerald Still, acting director of the centre. Usually the centre will follow the ARS practice of establishing public patents and refusing industry support that stipulates secrecy and exclusive rights. Dr Still, formerly National Program Leader at ARS in Beltsville, Maryland, has the task of coordinating research activities, arranging cooperative agreements and recruiting financial support. He hopes to supplement the annual budget provided by ARS with grants from other public and private agencies and industry.
Bruni Kobbe

\section{Nature index of biotechnology stocks}

\begin{tabular}{|c|c|c|c|c|c|}
\hline $\begin{array}{l}\text { 12-Month } \\
\text { high }\end{array}$ & $\begin{array}{l}\text { 12-Month } \\
\text { low }\end{array}$ & Company & $\begin{array}{l}\text { Close } \\
\text { previous } \\
\text { month }\end{array}$ & $\begin{array}{l}\text { Close } \\
31 \text { August }\end{array}$ & Change \\
\hline 14 & 6 & Biogen (Switzerland) & $63 / 4$ & 8 & $+11 / 4$ \\
\hline 2 & 1 & Bio-Logicals (Canada) & $11 / 8$ & $11 / 4$ & $+1 / 8$ \\
\hline $14^{3 / 8}$ & $75 / 8$ & Bio-Response (USA) & $81 / 8$ & $91 / 2$ & $+3 / 8$ \\
\hline 14 & $93 / 4$ & Cetus (USA) & $93 / 8$ & $11^{3} / 8$ & +2 \\
\hline $10^{3 / 8}$ & $41 / 4$ & Collaborative Research (USA) & $51 / 4$ & $61 / 4$ & +1 \\
\hline $19^{7} / 8$ & $11 \frac{1}{2}$ & Damon (USA) & 13 & $14 \frac{1}{2}$ & $+11 / 2$ \\
\hline $261 / 4$ & $11^{3 / 4}$ & Enzo-Biochem (USA) & $12 \frac{1}{1 / 2}$ & $14 \frac{1}{4}$ & $+13 / 4$ \\
\hline $10^{1 / 8}$ & $41 / 4$ & Flow General (USA) & $43 / 4$ & $53 / 8$ & $+5 / 8$ \\
\hline $421 / 4$ & $283 / 4$ & Genentech (USA) & 33 & $33^{1 / 4}$ & $+1 / 4$ \\
\hline $103 / 4$ & $41 / 2$ & Genetic Systems (USA) & 5 & $67 / 8$ & $+17 / 8$ \\
\hline $171 / 4$ & $81 / 4$ & Genex (USA) & $11^{1} / 8$ & 12 & $+7 / x$ \\
\hline 23 & 11 & Hybritech (USA) & $11 \frac{1}{4}$ & $14^{1 / 4}$ & +3 \\
\hline $161 / 4$ & $73 / 4$ & Molecular Genetics (USA) & $83 / 4$ & $10^{1 / 4}$ & $+1 \frac{1}{2}$ \\
\hline $151 / 2$ & $81 / 4$ & Monoclonal Antibodies (USA) & $81 / 4$ & 10 & $+13 / 4$ \\
\hline $60^{7} / 8$ & 39 & Novo Industri A/S (Denmark) & $40^{3} / 8$ & $371 / 4$ & $-31 / 8$ \\
\hline $223 / 4$ & $14 \frac{1}{2}$ & Pharmacia (Sweden) & $171 / 8$ & 19 & $+1 \frac{7}{8}$ \\
\hline
\end{tabular}

Closing prices are for the last Friday of the month. For over-the-counter stocks, bid price is quoted; for stocks on the American and New York exchanges, the transaction price. Nature's weighted index of biotechnology stocks stood at 149 on 31 August, compared with 138 a month earlier. Data from E.F. Hutton, Inc. 